\title{
Riparian forest fragments in rice fields under different management: differences on hymenopteran parasitoids diversity
}

\author{
G. S. Silva ${ }^{1,2 *(\mathbb{D}) \text {, S.M. Jahnke }{ }^{2} \text { (D) and N.F. Johnson }}{ }^{3}$ \\ ${ }^{1}$ Departamento de Fitosanidade, Faculdade de Agronomia, Universidade Federal do Rio Grande do Sul - UFRGS, \\ Av. Bento Gonçalves, 7712, CEP 91540-000, Porto Alegre, RS, Brasil \\ ${ }^{2}$ Universidade Federal do Rio Grande do Sul - UFRGS, Programa de Pós-graduação em Fitotecnia, \\ Av. Bento Gonçalves, 7712, CEP 91540-000, Porto Alegre, RS, Brasil \\ ${ }^{3}$ The Ohio State University, 1315 Kinnear Road, Columbus, OH, USA \\ *ss.gisele@gmail.com
}

Received: April 16, 2018 - Accepted: June 29, 2018 - Distributed: February 28, 2020

(With 6 figures)

\begin{abstract}
Hymenopteran parasitoids are important biological control agents in agroecosystems, and their diversity can be increased with habitat heterogeneity. Thus, the purpose of the study is to evaluate the influence of distance of rice-growing areas from natural fragment, type of crop management (organic and conventional) and crop stages (vegetative and reproductive stages) on parasitoids family diversity. The work took place in two irrigated rice crops, one with organic management (O.M.) and another one with conventional management (C.M.), in the municipality of Nova Santa Rita, RS, Brazil, during the 2013/2014 and 2014/2015 seasons. The parasitoids were collected with Malaise trap arranged at different distances in relation to the native vegetation surrounding the rice crop in both places. Specimens were collected twice a month from seeding until the rice harvest. Average abundance between management, distances and rice development were compared. The most abundant families were Platygastridae, Mymaridae, Encyrtidae, Eulophidae and Trichogrammatidae. Parasitoid average abundance was significantly higher on OM only in the second season. There was a negative correlation between distance from native vegetation and parasitoid abundance in C.M. areas. There were differences in the composition of the parasitoid assembly between the phenological stages of rice.
\end{abstract}

Keywords: conservative biological control, parasitoids, rice, habitat heterogeneity, native vegetation.

\section{Fragmentos de floresta riparia em áreas de cultivo de arroz sob diferentes manejos: diferenças através diversidade de himenópteros parasitoides}

\begin{abstract}
Resumo
Os himenópteros parasitoides são importantes agentes de controle biológico em agroecossistemas com sua diversidade variando de acordo com a heterogeneidade de habitat. Nesse sentido, o objetivo deste trabalho foi avaliar a influência da distância de áreas com fragmentos de vegetação natural das áreas de cultivo de arroz, o tipo de manejo (orgânico ou convencional) e os estágios da cultura (vegetativo e reprodutivo) na diversidade de famílias de parasitoides. O trabalho foi conduzido em duas áreas com plantio de arroz irrigado, uma com manejo orgânico (MO) e outra com manejo convencional (CM), no município de Nova Santa Rita, RS, Brasil, durante a safra 2013/2014 e 2014/2015. Os parasitoides foram coletados com armadilha Malaise colocadas sob diferentes distâncias em relação a vegetação nativa circundante ao cultivo em ambas as áreas. Os espécimes foram coletados duas vezes ao mês da semeadura até a colheita. Foram comparadas a abundância média entre os manejos, distâncias e estágio de desenvolvimento do arroz. As famílias mais abundantes foram Platygastridae, Mymaridae, Encyrtidae, Eulophidae e Trichogrammatidae com suas abundâncias variando ao longo da safra. A abundância média de parasitoides foi significativamente maior no MO somente na segunda safra. Houve uma correlação negativa entre a distância da vegetação nativa e a abundância de parasitoides. Houve diferença na composição da assembleia de parasitoides entre os estágios fenológicos do arroz.
\end{abstract}

Palavras-chave: controle biológico conservativo, parasitoides, arroz, heterogeneidade de habitat, vegetação nativa.

\section{Introduction}

Rice (Oryza sativa L.) is the second most cultivated cereal in the world, occupying an area of 158 million hectares and corresponds to $29 \%$ of the grains used for human consumption (SOSBAI, 2014). The rice plant can be damaged by various phytophagous groups such as Hemiptera, Lepidoptera, Coleoptera and others (EMBRAPA, 2009). 
To control these pests, chemical insecticides based on neonicotinoid, diamide, pyrethroid and carbamate are mainly used in conventional management (Brasil, 2016). On the other hand, the production of organic rice is based on eliminating the use of synthetic chemical inputs such as fertilizers, pesticides and growth regulators, and promoting alternative technologies such as mechanization and tillage in the management of pests, including weeds, diseases and insects (EMBRAPA, 2009). In addition, the maintenance of permanent preservation areas and the mitigation of anthropogenic pressure on natural and modified ecosystems are environmental aspects that organic rice production systems seek to obtain certification (EMBRAPA, 2009).

Parasitoids are one of the most important groups of biological control agents in the control of pest insect populations in agricultural systems, both by the natural occurrence of the species in the environment and by their use in classic biological control programs (Hanson and Gauld, 2006). Parasitoid diversity associated with different cultivation systems is determined by environmental, biological, and management factors (Chay-Hernandez et al., 2006). In large monocultures, the diversity can be suppressed by pesticides, simplification of vegetation, and other environmental disturbances (Altieri et al., 2003). In less disturbed agricultural ecosystems, the diversity of these agents appears to be related to the diversity of crops, weeds, ground cover and native vegetation next to cultivated systems (Liere et al., 2015).

In this context, the purpose of the study is to evaluate the influence of distance of rice-growing areas from natural fragment, type of crop management (organic and conventional) and crop stages (vegetative and reproductive stages) on parasitoids family diversity.

\section{Material and Methods}

\subsection{Study area}

The study was carried out in the municipality of Nova Santa Rita, RS, in the metropolitan region of Porto Alegre in the phytogeographic region of the Jacuí watershed, during the 2013/2014 and 2014/2015 seasons. In this region many native trees species occur such as 'maricá' (Mimosa bimucronata (DC) Kuntze), 'corticeira' (Erythrina falcata Benth.), fig tree (Ficus luschnatiana (Miq.) Miq.), 'angico' (Parapiptadenia rigida (Benth.) Brenan), Surinam cherry (Eugenia uniflora L.), 'branquilho' (Sebastiania commersoniana (Baill.) L.B. Sm. \& Downs), 'açoita-cavalo' (Luehea divaricata Mart. \& Zucc.) and many others (Ministério do Desenvolvimento Agrário, 2010). The vegetation near to the irrigated rice area is a riparian forest.

\subsubsection{Organic Rice crop}

The irrigated rice area with organic management (O.M.) is part of the Capela Settlement (Landless Rural Workers Movement Settlement) in Nova Santa Rita. It has a total area of 2169.37 hectares (INCRA, 2007), of which 580 ha belong to COOPAN (Agricultural Production
Cooperative Nova Santa Rita). Of these, 220 continuous hectares are allocated for organic rice, which is certified by the Ecological Market Institute (Instituto de Mercado Ecológico - IMO) (Lanner, 2011). In the settlement, an area of 273.52 ha $(13.68 \%$ of the total) is designated as a permanent preserve (native forest). In the organic rice field, the levees are maintained with wild vegetation.

In the first season (December, 2013 to April, 2014), five points were defined for the installation of traps centered around this coordinate $29^{\circ} 47^{\prime} 16.62^{\prime}$ S and $51^{\circ} 21^{\prime} 00.91^{\prime \prime} \mathrm{W}$. The first sampling point was placed on the edge of the riparian forest with some influence of the shade of the trees. From it, the other traps were positioned in a straight line into the crop.

In the area where the traps were installed, it was used the pre-germinated planting system with cultivar EPAGRI 108 which has late cycle, lodging resistance and indirect iron toxicity. It is moderately resistant to panicle blast and stands out for its excellent grain quality and high reproductive potential (SOSBAI, 2014).

Due to the difficult access to the area in the first year, another five points were defined in the second year (November, 2014 to March, 2015) for the installation of traps (2946'48.90" S, 51 ${ }^{\circ} 21^{\prime}$ '48.38' W). The management of the area was the same as in the first year.

In the first year, the traps were separated $100 \mathrm{~m}$ from each other, in a distance gradient starting from inside the forest to the middle of the crop, along a transecto (Figure 1). In the second year, the distance was extended to $200 \mathrm{~m}$. Each trap site was named by the location of the Malaise trap, being O5 (Spot 5 - inside the forest), O4 (Spot 4), O3 (Spot 3), O2 (Spot 2), O1 (Spot 1 - greatest distance from forest) (Figure 1).

\subsubsection{Conventional Rice crop}

The irrigated rice area with conventional management (C.M.) is located in the 'Gaúcha' Farm, a private property of 300 hectares approximately $2.5 \mathrm{~km}$ distant from the organic management area and bordered to the southwest by the Caí River. Tillage is the planting system, and the cultivar used was IRGA428, which has a medium cycle, high productivity potential, tolerance to herbicides, tolerance to toxicity from iron excess, is moderately susceptible to leaf blast and susceptible to blast on panicle (SOSBAI, 2014).

The conventional management adopted by the producer follows the IRGA recommendations, with the use of chemical inputs and application of agricultural pesticides according to the annual manuals for rice management (SOSBAI, 2012). For insect collecting, the experimental design was the same of the organic management area (Figure 1), with the points set between $29^{\circ} 46^{\prime} 16.65^{\prime \prime} \mathrm{S}$ and $51^{\circ} 21^{\prime} 43.31^{\prime \prime} \mathrm{W}$, the same in both seasons. In the conventional rice field, the levees were maintained without wild vegetation by chemicals spraying.

As in the O.M. area, in the first year (December, 2013 to April, 2014), the traps were from each other by $100 \mathrm{~m}$, along a transecto, and in the second (November, 2014 to March, 2015), the distance was extended to $200 \mathrm{~m}$. 


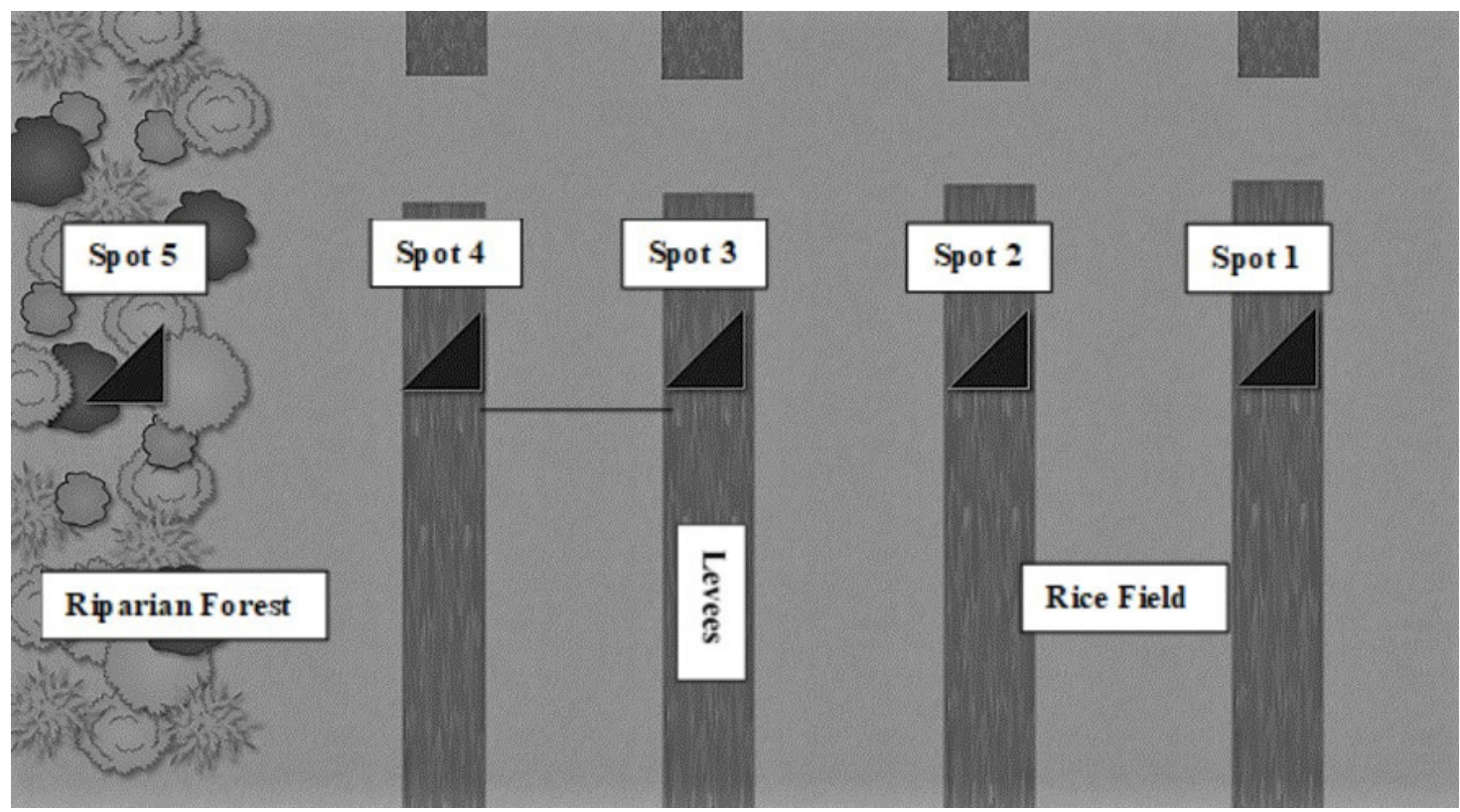

Figure 1. Layout showing Malaise traps ( 4 ) position on rice field and native vegetation in both areas, Organic Management area (O.M.) and Conventional Management area (C.M.), in Nova Santa Rita, RS. (一) Distance between traps (100m first season; $200 \mathrm{~m}$ second season).

Each spot also was named by the location of Malaise trap, being C5 (Spot 5), C4 (Spot 4), C3 (Spot 3), C2 (Spot 2), C1 (Spot 1).

In the first season regulators insecticides were used (buprofezin and benzylurea) and in the second season were used non-selective (neurotoxic) insecticides (neonicotinoids and pyrethroids) (farmer personal communication Mr. Denis).

\subsection{Hymenoptera sampling and identification}

For sampling the parasitoids, five Malaise traps (Townes, 1972) were placed in the levees of each area (Figure 1). The collection method was improved, by putting PVC pipes cut in half to simulate a "gutter" in each trap, so that insects which have not reached the collecting head could drop in the "gutter" (containing water and detergent) located on the ground, comprising the entire length of the trap (Gullan and Cranston, 2008).

Samples were collected every two weeks during two rice seasons, 2013/2014 and 2014/2015, from seeding to harvest. The traps remained mounted in the points for 24 hours and thereafter the vials with the collected insects were taken. These were transferred to $70 \%$ alcohol, labeled with the collection site, and transported to the Laboratory for Biological Control of Insects (CBLAB) of UFRGS. In the laboratory, the samples were sorted using a stereomicroscope Nikon SMZ445, selecting the hymenopteran parasitoids. The identification of families followed the classification adopted by Goulet and Huber (1993) and Sharkey (2007). The specimens were deposited in the Education Collection at Laboratory for Biological Control of Insects (CBLAB) of UFRGS in Agronomy University.

\subsection{Statistical analyses}

Considering the extent of the two areas and their characteristics, it was impossible to make replicas of the samples, so that evaluations were considered exploratory.

The average capture of parasitoids was compared between areas and between crop development periods, considering the four traps installed inside the crop as pseudoreplicas, through Shapiro-Wilk normality test and analysis of variance (Kruskal-Wallis test).

The rice developmental stages were identified according to Counce et al. (2000). Here we named indicated O.V. or C.V. (organic or conventional vegetative stage of rice) and O.R or C.R. (organic or conventional reproductive stage of rice), respectively.

For evaluating the abundance of parasitoids over the gradient of distance from traps in relation to the native vegetation, Pearson correlation test was used through the BioEstat 5.3 program (Ayres et al., 2011).

Correspondence Analysis (CA) and Bray-Curtis Cluster Analysis plots were built through the PAST program (Hammer et al., 2001). Plots are constructed with the main components of lines and columns allowing visualization of the relationship between groups, where the proximity of the points relating to the line (parasitoid families) and column (spots and rice stages) indicates association and the distance indicates repulsion (Greenacre and Hastie, 1987). The Cluster Analysis groups the data in a dendogram, in which the level of similarity (or dissimilarity) is indicated on the vertical scale. On the horizontal axis, the sample elements are reported in a convenient order for the clustering (Mingoti, 2005). 


\section{Results}

\subsection{Faunistic data}

\subsubsection{First Season (2013-2014)}

In the first season, 1,104 individuals were collected in O.M. area, distributed in 21 families; and 860 individuals in the C.M. area, distributed in 18 families. The total average of captured individuals/trap/day was $30.3 \pm 5.42$ in the O.M. area and $22.3 \pm 7.32$ in the C.M. area in the first season, with no significant difference $(\mathrm{H}=2.08$, $\mathrm{df}=1, \mathrm{p}=0.1$ ).

Regarding the development stage of rice within each area, in the O.M., the total capture average was significantly lower in the vegetative stage $(24.45 \pm 6.96)$ than in the reproductive $(40.1 \pm 4.74)(\mathrm{H}=5.33 ; \mathrm{df}=1 ; \mathrm{p}=0.02)$. In the C.M., however, there was no significant difference between the vegetative $(16.8 \pm 10.58)$ and reproductive stages $(29.31 \pm 4.06)(\mathrm{H}=3 ; \mathrm{df}=1 ; \mathrm{p}=0.08)$.

Considering the same development stage between areas, in the reproductive stage, a significantly higher average of captures $(40.08 \pm 4.74)$ in the O.M. was observed than in the C.M. over this period $(29.31 \pm 4.06)(\mathrm{H}=5.33$; $\mathrm{df}=1 ; \mathrm{p}=0.02$ ). In the vegetative period, there was no significant difference between the O.M. $(24.45 \pm 6.95)$ and the C.M. $(16.8 \pm 10.58)(\mathrm{H}=1.33 ; \mathrm{df}=1 ; \mathrm{p}=0.24)$.

The most abundant families in the O.M. were Platygastridae and Mymaridae. In the C.M., the most abundant were Encyrtidae and Platygastridae (Table 1).

\subsubsection{Second Season (2014-2015)}

In the second year's season, 1,064 parasitoids were collected in the O.M. area, divided into 19 families, and 389 individuals were collected in the C.M. area, distributed in 16 families. The total average of trapped individuals in the O.M. area was $25.38 \pm 6.85$ trap/day, significantly higher than in the C.M. area $(8.41 \pm 3.40)(\mathrm{H}=5.33$; $\mathrm{df}=1 ; \mathrm{p}=0.02)$.

In a comparison of developmental stages within each area, the vegetative stage $(17.33 \pm 3.12)$ averaged significantly lower captures than the reproductive $(29.41 \pm 9.36)$ in the O.M. $(\mathrm{H}=4.08 ; \mathrm{df}=1 ; \mathrm{p}=0.04)$, however, there was no difference between stages in the C.M. (vegetative: $10.06 \pm 2.46$ and reproductive: $6.7 \pm 4.59)(\mathrm{H}=2.08$; $\mathrm{df}=1 ; \mathrm{p}=0.14)$.

Comparison of trap catches in the same development stage of rice between areas showed that in the vegetative

Table 1. Hymenoptera parasitoids families sampled in the first (2013/2014) and second crop season (2014/2015) over vegetative stage (Veg) and reproductive stage (Rep) of rice crop in organic management area (O.M.) and conventional management area (C.M.), Nova Santa Rita, RS.

\begin{tabular}{|c|c|c|c|c|c|c|c|c|c|c|c|c|}
\hline \multirow{3}{*}{ Family } & \multicolumn{6}{|c|}{$1^{\circ}$ Crop Season } & \multicolumn{6}{|c|}{$2^{\circ}$ Crop Season } \\
\hline & \multicolumn{3}{|c|}{ O.M. } & \multicolumn{3}{|c|}{ C.M. } & \multicolumn{3}{|c|}{ O.M. } & \multicolumn{3}{|c|}{ C.M. } \\
\hline & Veg & Rep & $\begin{array}{c}\text { Fr } \\
(\%)\end{array}$ & Veg & Rep & $\begin{array}{c}\text { Fr } \\
(\%)\end{array}$ & Veg & Rep & $\begin{array}{c}\text { Fr } \\
(\%)\end{array}$ & Veg & Rep & $\begin{array}{c}\mathrm{Fr} \\
(\%)\end{array}$ \\
\hline Platygastridae & 131 & 137 & 24.2 & 81 & 94 & 20.3 & 59 & 120 & 16.8 & 60 & 55 & 29.5 \\
\hline Mymaridae & 106 & 79 & 16.7 & 102 & 43 & 16.8 & 47 & 186 & 21.9 & 37 & 43 & 20.5 \\
\hline Eulophidae & 49 & 81 & 11.8 & 12 & 15 & 3.1 & 58 & 212 & 25.4 & 17 & 10 & 6.9 \\
\hline Encyrtidae & 54 & 67 & 10.9 & 27 & 182 & 24.2 & 12 & 50 & 5.8 & 15 & 18 & 8.5 \\
\hline Trichogrammatidae & 79 & 54 & 12 & 56 & 78 & 15.5 & 14 & 38 & 4.9 & 21 & 29 & 12.8 \\
\hline Ichneumonidae & 45 & 27 & 6.5 & 12 & 5 & 2 & 25 & 65 & 8.5 & 6 & 6 & 3.1 \\
\hline Ceraphronidae & 16 & 11 & 2.4 & 18 & 50 & 7.9 & 8 & 13 & 2 & 7 & 6 & 3.3 \\
\hline Braconidae & 21 & 28 & 4.4 & 16 & 20 & 4.2 & 16 & 36 & 4.9 & 20 & 7 & 6.9 \\
\hline Figitidae & 19 & 11 & 2.7 & 13 & 0 & 1.5 & 9 & 20 & 2.7 & 8 & 3 & 2.8 \\
\hline Diapriidae & 9 & 5 & 1.3 & 8 & 1 & 1 & 3 & 6 & 0.8 & 3 & 1 & 1 \\
\hline Bethylidae & 16 & 3 & 1.7 & 2 & 1 & 0.3 & 7 & 5 & 1.1 & 4 & 2 & 1.5 \\
\hline Chalcididae & 8 & 4 & 1.1 & 5 & 2 & 0.8 & 1 & 13 & 1.3 & 3 & 1 & 1 \\
\hline Eupelmidae & 9 & 1 & 0.9 & 2 & 2 & 0.5 & 2 & 10 & 1.1 & 1 & 1 & 0.5 \\
\hline Pteromalidae & 3 & 0 & 0.3 & 5 & 2 & 0.8 & 4 & 9 & 1.2 & 0 & 1 & 0.3 \\
\hline Aphelinidae & 5 & 5 & 0.9 & 1 & 1 & 0.2 & 0 & 3 & 0.3 & 1 & 0 & 0.3 \\
\hline Chrysididae & 4 & 1 & 0.5 & 0 & 0 & 0 & 1 & 2 & 0.3 & 0 & 0 & 0 \\
\hline Evaniidae & 3 & 2 & 0.5 & 0 & 0 & 0 & 1 & 2 & 0.3 & 0 & 0 & 0 \\
\hline Signiphoridae & 0 & 1 & 0.1 & 0 & 0 & 0 & 0 & 4 & 0.4 & 0 & 0 & 0 \\
\hline Dryinidae & 2 & 0 & 0.2 & 1 & 0 & 0.1 & 0 & 3 & 0.3 & 0 & 0 & 0 \\
\hline Torymidae & 3 & 0 & 0.3 & 0 & 0 & 0 & 0 & 0 & 0 & 0 & 0 & 0 \\
\hline Megaspilidae & 0 & 0 & 0 & 1 & 1 & 0.2 & 0 & 0 & 0 & 0 & 0 & 0 \\
\hline Eurytomidae & 3 & 2 & 0.5 & 1 & 0 & 0.1 & 0 & 0 & 0 & 0 & 0 & 0 \\
\hline Proctrotupidae & 0 & 0 & 0 & 0 & 0 & 0 & 0 & 0 & 0 & 0 & 3 & 0.8 \\
\hline TOTAL & 585 & 519 & 100 & 363 & 497 & 100 & 267 & 797 & 100 & 203 & 186 & 100 \\
\hline
\end{tabular}


stage the O.M. averaged significantly higher captures $(17.33 \pm 3.12)$ than the C.M. $(10.06 \pm 2.46)(\mathrm{H}=5.33$; $\mathrm{df}=1 ; \mathrm{p}=0.02)$, as well as in the reproductive stage, with significantly higher captures in the O.M. (29.41 \pm 22.54$)$ than in the C.M. $(6.7 \pm 2.28)(\mathrm{H}=7.04 ; \mathrm{df}=1 ; \mathrm{p}=0.008)$.

The most abundant families in the O.M. were Eulophidae, Mymaridae and Platygastridae. In the C.M., they were Platygastridae, Mymaridae and Trichogrammatidae (Table 1).

\subsection{Native forest distance effects on parasitoid abundance in rice fields}

\subsubsection{First Season}

There was a negative correlation between the number of insects captured and the distance from the forest area for the C.M. (Figure 2A), and 92\% of this variation may be explained by the distance in relation to the forest next to the planting area. In the O.M., however, this correlation could not be detected.

\subsubsection{Second Season}

In the second season, there was no correlation between the distance gradients in any of the areas (Figure 2B), even with increased distance between traps.

\subsection{Association between sampling spots, management, phenological stages and parasitoid families}

In the correspondence analysis (Figure 3), the points were represented in two-dimensional axes, indicating that the association between lines (families of parasitoids) and columns (points and stages of rice) explains $60 \%$ of the relation between two axes in the first season and $69 \%$ in the second season. In the first season, samples are mixed on both sides of the $\mathrm{x}$ and $\mathrm{y}$ axes, showing similar composition between areas (Figure 3). Nonetheless, some families had higher relationships with certain sampling points and phenological periods of the plant. Mymaridae and Trichogrammatidae, showing confluence with the sampling areas of O.M. and both the phenological stages and with the sampling areas of C.M. and its vegetative phenological stage. On the other hand, Encyrtidae showed greater relationship with sampling areas of the C.M. in the reproductive stage. The points Organic $1(\mathrm{O} 1)$ and Organic $2(\mathrm{O} 2)$ were the most dissimilar from the others.

In the second season (Figure 4), the samples of the organic and conventional managements showed dissimilarities between them, since they appear to be distributed on distinct sides, with different families relating to each area. Nevertheless, the most abundant families exhibit similarities to each other along the $y$ axis. Platygastridae, Mymaridade and Encyrtidae appear to be in the same position on the y axis, showing to have the same importance for the composition to which they belong, being Platygastridae, on the right side, related to C.M.; Eulophidae, on the left side, related to O.M.; and Mymaridae, in center, related to both areas.

Differences between the composition and abundance of families are perceived between the two sampling years for the areas through cluster analysis. The high cophenetic correlation in the two years ( 0.94 and 0.85 , respectively) confirms the adjustment of data to the Bray-Curtis model (Figures 5 and 6).

In the first season, there was similarity between the different sampled points, regardless of the adopted management. Considering a cut-off point in $60 \%$, only the organic management points $(\mathrm{O} 1$ and $\mathrm{O} 2)$ were dissimilar from the others (Figure 5).

In season 2, two clusters are distinct, clearly pointing out similarities between the managements used (Figure 6). All points within the crop of the organic management area showed about $75 \%$ similarity. The points relating to the conventional management area showed similarity ranging from $60 \%$ to $70 \%$. The lowest percentage of similarity $(55 \%)$ was that of the organic 5 (O5), presenting itself as independent of the others.
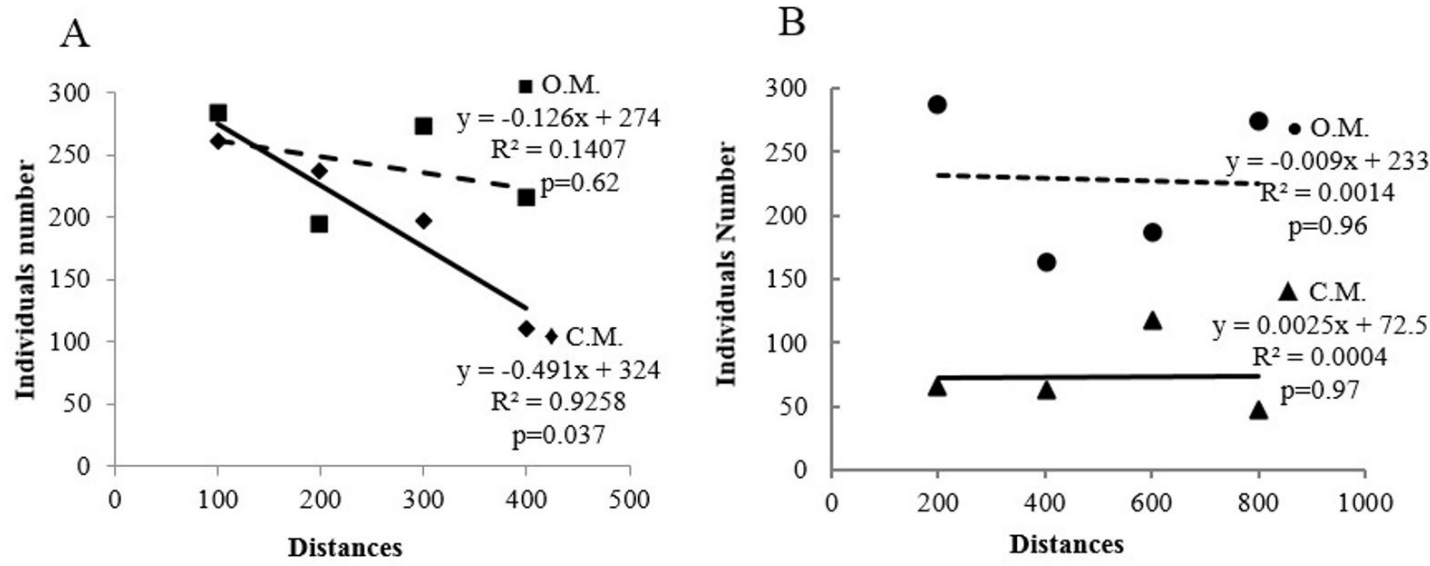

Figure 2. Correlation between distances in First Crop Season (A). Samples spots with 0, 100m, 200m, 300m e 400m from native vegetation (O.M. $\mathrm{p}>0.05$ e C.M. $\mathrm{p}<0.05$. Pearson Test). Correlation between distances in Second Crop Season (B). Samples spots with $0,200 \mathrm{~m}, 400 \mathrm{~m}, 600 \mathrm{~m}$ e $800 \mathrm{~m}$ from native vegetation (O.M. $\mathrm{p}>0.05$ e C.M. p>0.05. Pearson Test). 


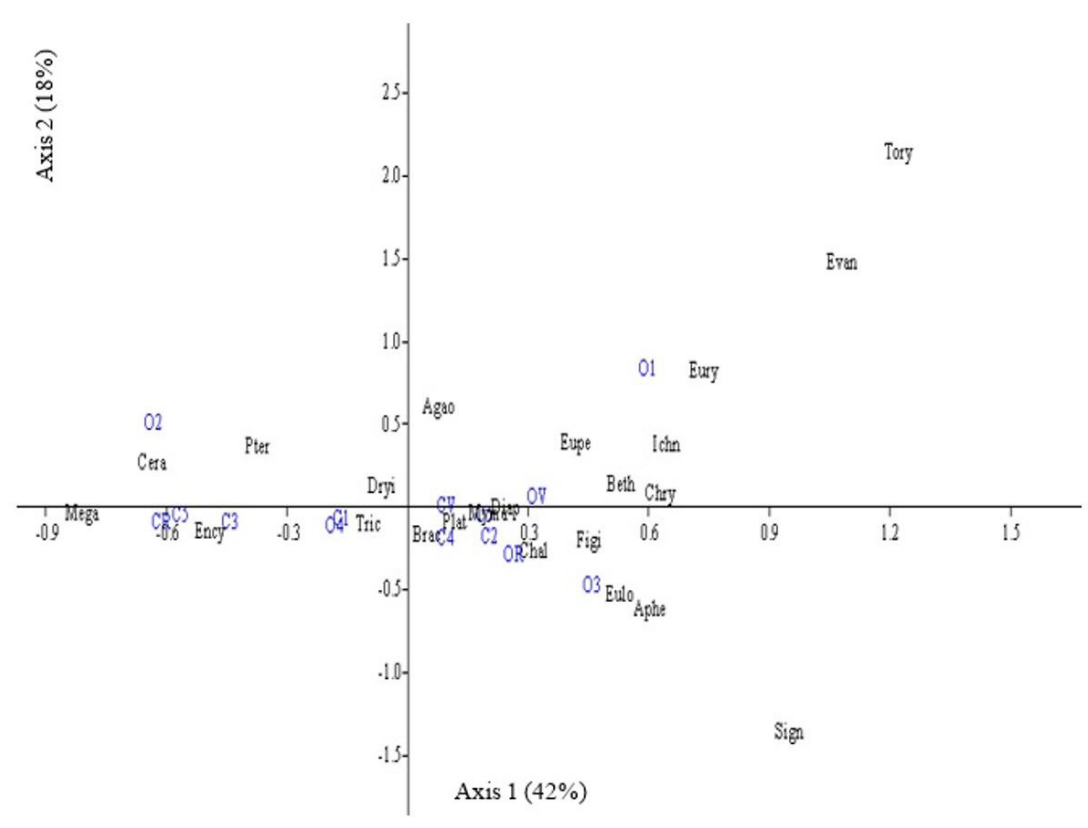

Figure 3. Correspondence Analyses. Relation between sample spot in each management, rice crop development stages $(\mathrm{V}=$ vegetative; $\mathrm{R}=$ reproductive $)$ in each point of the areas with organic management $(\mathrm{O})$ and conventional $(\mathrm{C})$ and parasitoids families in the first season (2013/2014). Parasitoids families Abbreviation: Megaspilidae (Mega), Ceraphronidae (Cera), Encyrtidae (Ency), Pteromalidae (Pter), Trichogrammatidae (Tric), Dryinidae (Dryi), Agaonidae (Agao), Braconidae (Brac), Platygastridae (Plat), Mymaridae (Mym), Diapriidae (Diap), Chalcididae (Chal), Eupelmidae (Eupe), Bethylidae (Beth), Figitidae (Figi), Eulophidae (Eulo), Aphelinidae (Aphe), Chrysididae (Chry), Eurytomidae (Eury), Ichneumonidae (Ichn), Evaniidae (Evan), Torymidae (Tory) and Signiphoridae (Sign).

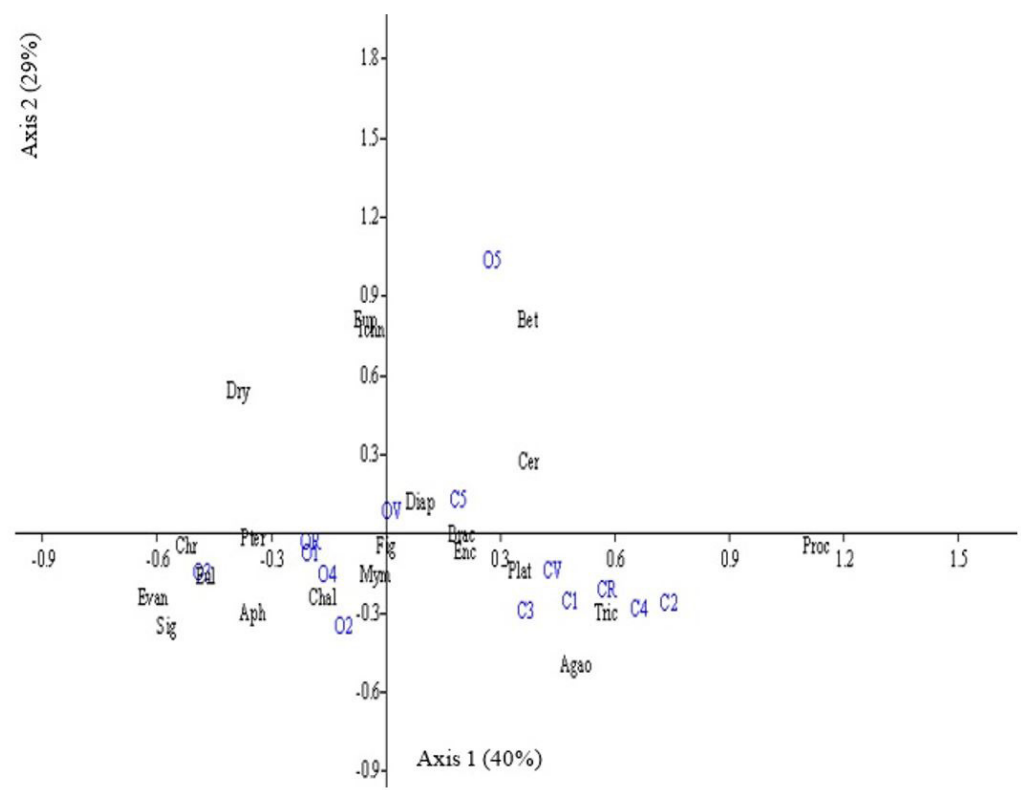

Figure 4. Correspondence Analyses. Relation between sample spot in each management, rice crop development stages $(\mathrm{V}=$ vegetative; $\mathrm{R}=$ reproductive $)$ in each point of the areas with organic management $(\mathrm{O})$ and conventional $(\mathrm{C})$ and parasitoids families in the second season (2014/2015). Parasitoids families Abbreviation: Ceraphronidae (Cer), Encyrtidae (Enc), Pteromalidae (Pter), Trichogrammatidae (Tric), Agaonidae (Agao), Braconidae (Brac), Platygastridae (Plat), Mymaridae (Mym), Diapriidae (Diap), Chalcididae (Chal), Eupelmidae (Eup), Bethylidae (Bet), Figitidae (Fig), Eulophidae (Eul), Aphelinidae (Aph), Chrysididae (Chr), Ichneumonidae (Ichn), Evaniidae (Evan), Proctrotupidae (Proc) and Signiphoridae (Sig). 


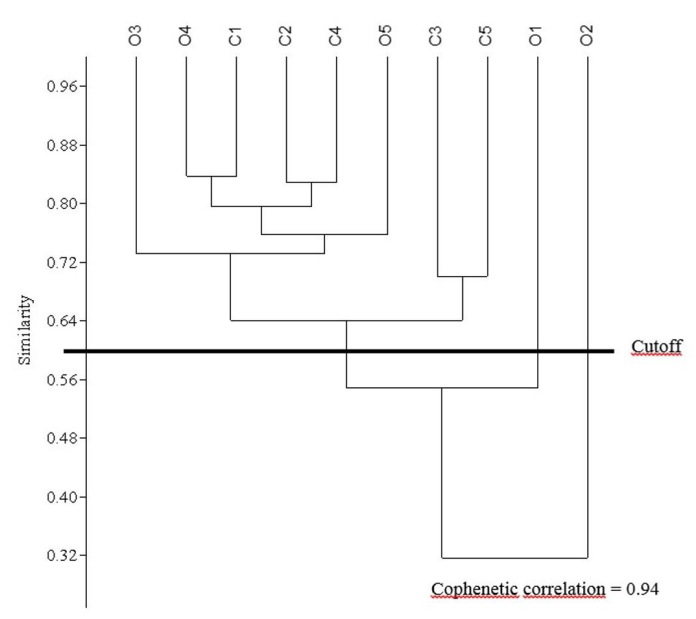

Figure 5. Cluster Analysis of similarity (Bray-Curtis Index). Relation between abundance distribution in each family and sample spot in both areas (O.M. and C.M.) in first season $(2013 / 2014)$. Cophenetic correlation $=0.94$; Cutoff $=60 \%$.

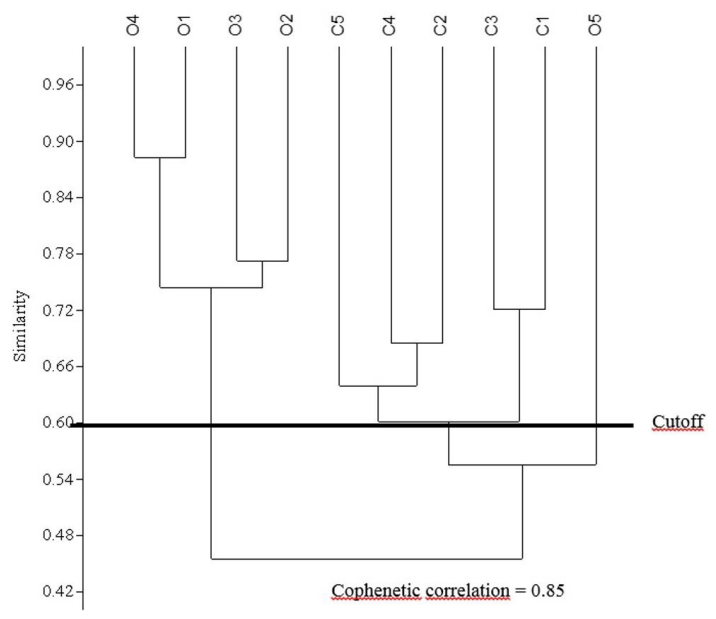

Figure 6. Cluster Analysis of similarity (Bray-Curtis Index). Relation between abundance distribution in each family and sample spot in both areas (O.M. and C.M.) in second season $(2014 / 2015)$. Cophenetic correlation $=0.85$, Cutoff $=60 \%$.

\section{Discussion}

A comparison of the results between the two seasons $(2013 / 2014$ and 2014/2015) showed that in the O.M. area, the abundance of individuals was similar despite the distance between sampling points. However, in the C.M., there was much less abundance in the second season. This may be due to the use of non-selective (neurotoxic) insecticides (neonicotinoids and pyrethroids) applied to the crop in 2014/2015, different from the first season, when growth regulators insecticides were used (buprofezin and benzylurea) (farmer personal communication Mr. Denis). Neurotoxic are the main synthetic insecticides, as they act quickly to stop damage to crops and their cost, in general, is low. They act in inhibition of acetylcholinesterase (AChE), responsible for the hydrolysis of acetylcholine (ACh) in the synaptic regions of cholinergic nerve endings (Casida and Durkin, 2013), Thus, they reach non-target organisms, including beneficial insects like pollinators and natural enemies. On the other hand, the products that act on chitin synthesis are either ecdysteroid receptor agonists and are generally more selective to natural enemies because they act only on immature stages, having a smaller impact on adults (Bastos et al., 2006), which may explain the difference in the results of this work.

In Brazil, Platygastridae, mainly the genera Telenomus and Trissolcus, are important biological control agents of Pentatomidae in rice crops (Maciel et al., 2007; Riffel et al., 2010). Their high abundance within the rice fields is associated with resource availability in the crop, such as nectar, polen, mating and available hosts. Pentatomidae is common both in the vegetative and reproductive stages of rice (SOSBAI, 2014), that can accounting for the great number of Platygastridae in both development stages of the crop.

Other highlighted families were Eulophidae (O.M.) and Encyrtidae (C.M.). For rice, Gurr et al. (2011) listed Aprostocetus formosanus (Timberlake, 1921) (Eulophidae) as parasitoids of Delphacidae in the Philippines, Vietnam, Malaysia and Thailand. Other authors have also reported individuals of Eulophidae in rice crops (Nacro et al., 1997; Williams et al., 1999; Bayegan et al., 2015), and Gumovsky et al. (2006) described a new species of Eulophidae, genus Closterocerus, parasitoid of Dicladispa armigera (Olivier, 1808) (Coleoptera: Chrysomelidae), a major rice pest in Southeast Asia and Australasia. In rice cultivation in Rio Grande do Sul, Eulophidae also was the most abundant parasitoid family and the phytophagous registered were Curculionidae, Pentatomidae, Delphacidae and Cicadellidae (Fritz et al., 2011).

The second most abundant family in C.M., Encyrtidae has records of hosts of rice pests in various regions of the world. For example, Kraker et al. (1999) noted the parasitism of Cnaphalocrocis medinalis (Guenée, 1854) and Marasmia spp. (Lepidoptera: Pyralidae), rice pests increasing in abundance since 1960 in many Asian countries, by Copidosomopsis nacoleiae (Eady, 1960) (Encyrtidae) (Khan et al., 1988; Dale, 1994). Ooencyrtus nezarae Ishii, 1928 and Xenoencyrtus niger Riek, 1962, both species introduced in the Neotropics, are parasitoids of Pentatomidae eggs (Hanson and Gauld, 2006; Taxapad, 2012). In Brazil, Ooencyrtus submetallicus (Howard, 1886) was recorded as a parasitoid of $T$. limbativentris eggs in rice crops in Maranhão (Maciel et al., 2007).

Mymaridae, a family among the most abundant in both seasons, especially in the vegetative stage in the first season, and reproductive stage in the second one, is known to attack, mostly, Auchenorrhyncha (Hemiptera). Nonetheless, this parasitoid family also attacks Coleoptera, Orthoptera and other Hemiptera (Hanson and Gauld, 2006). These small parasitoids of eggs are recorded attacking leafhoppers, which are rice pests, of Delphacidae present in Asia and Oceania (India, China, Japan, Malaysia, Singapore, 
Vietnam, Sri Lanka, the Philippines, Thailand, Korea, Taiwan, Indonesia) (Gurr et al., 2011). In Brazil, species like Tagosodes orizicolus (Muir, 1926) (Hemiptera: Delphacidae), Graphocephala sp. and Estianussp. (Hemiptera: Cicadellidae) (Didonet et al., 2001) and Deois incompleta (Walker, 1851) Mahanarva spectabilis (Distant, 1909) Mahanarava tristis (Fabricius, 1803) and Zulia pubescens (Fabricius, 1803) (Paladini et al., 2018) are recorded in rice. Therefore, the presence of Mymaridae species can be related with leafhopper on the crop.

In the C.M., the phenological stage did not influence the parasitoid composition. Other factors such as the habitat heterogeneity or the crop management may have induced the characteristics of the assembly, which has also been recorded in other studies (Tanaka et al., 2000; Gurr et al., 2011; Zhao et al., 2015).

The correlation between the distance from the native forest to the crop in relation to the abundance of parasitoids observed in the C.M. in the first season suggests the importance of this area in the presence of these natural enemies in that crop. It is important to emphasize that the riparian forest was located close to the crop, so the edge effect was expected to influence the diversity in the first sampling points. This influence was expected to decrease along the distance gradient, with the decrease in diversity. The role of these forest fragments in maintaining the richness and abundance of parasitoids has been described by Corbett and Plant (1993), Romeis et al. (2005) and Souza da Silva et al. (2016). In the second season, this correlation was not observed due to the large decrease in the abundance of parasitoids, already discussed with relation to the management.

In the organic management area, however, the correlation between the gradient of distance was not demonstrated in any of the seasons. This can possibly be explained by the fact that it is an organic management area, not receiving chemical inputs, which negatively affects the presence of parasitoids, even in central areas of the monoculture. Moreover, as in the O.M. there is wild levees vegetation, including the presence of flowering species that increase the richness of parasitoids (Simões-Pires et al., 2016). Therefore, the abundance may not be so dependent on the presence or proximity of the preserved area. Levees can serve as corridors extending the distances traveled by parasitoids (Gurr et al., 2011).

The levees have been neglected as a major reserve of plants and resources for natural enemies. Nectar can maximize the longevity and fecundity of parasitoids, and pollen may allow other natural enemies during the period of prey shortage (Zheng et al., 2003). Pest insects and natural enemies were more abundant and rich in the Philippines in rice fields surrounded by vegetated levees than in rice fields without this feature (Marcos et al., 2001; Gurr et al., 2011). The importance of wild vegetation in rice levees has already been described in crops with organic system, increasing the presence of predators and also parasitoids (Acosta et al., 2017; Simões-Pires et al., 2016). Thus, there is an important advantage, as parasitoids in large monocultures need to forage over large distances, leading to high costs in terms of time and energy (Powell, 1986), affecting their distribution within the crop and consequently the distribution and population of pests (Baggen and Gurr, 1998).

In the first season, generally samples are mixed on both sides of the axes, showing a relationship between them. This may be because, although with different managements, both areas are inserted in the same ecosystem with similar adjacent vegetation (Ministério do Desenvolvimento Agrário, 2010) and these environments with native vegetation can increase arthropod diversity, in general, and parasitoid diversity, more specifically, in the cultivated areas (Ferreira et al., 2014; Souza da Silva et al., 2016). Notwithstanding, in the second season samples of the organic and conventional managements showed dissimilarities as they appear to be distributed on different sides in the correspondence analysis chart. This may be related to a non-selective treatment of chemical inputs in the C.M., leading to a compositional difference between the organic management and the conventional management areas. The similarity of the points in the areas, disassociating the managements, was expected, considering that the extensive use of insecticides affects not only the pests but also beneficial insects (Tanaka et al., 2000; Gangurde, 2007), which leads to differences in their composition.

In the first sampling year, the sampling point organic $2(\mathrm{O} 2)$ had a similarity lower than $32 \%$ with other samples, being the point with greatest dissimilarity. This may be due to differences between the number of individuals being the point with the lowest abundance of platygastrids and trichogrammatids, besides has the greatest number of ceraphronids, which is the family with greater similarity to the $\mathrm{O} 2$. The sampling point $\mathrm{O} 1$ was also different from the others, but because of the composition of families, having more singletons (those species in which only one individual has been collected) and doubletons (only two individuals collected) than the others (6). The presence of rare species in an assembly provides higher diversity indices (Magurran, 2011) and may be responsible for the dissimilarities identified.

In season 2, the lowest percentage of similarity (55\%) was from the sampling point $\mathrm{O}$, gathering together the cluster of samples of the conventional management. The point $\mathrm{O} 5$ had a low number of mymarids and eulophids in relation to the other points and greater abundance of families Ichneumonidae, Bethylidae, Ceraphronidae and Eupelmidae. This similarity can also be seen through the correspondence analysis, which shows similarity between the point and these families. The association of a family to a certain point should be linked to the use of resources by the group, both of hosts (Plećaš et al., 2014) and alternative resources like nectar, pollen or refuge (Gurr et al., 2011). Thus, an assessment of the phytophagous fauna present in the area could give an indication of what contributes to the composition of species of parasitoids. This aspect, however, was not evaluated in this study. 
Other points showed similar compositions, and families Platygastridae, Mymaridae, Braconidae, Figitidae, Encyrtidae, Trichogrammatidae and Pteromalidae were the ones which contributed most to this in the first season. In the second, the families that contributed most were Platygastridae, Mymaridae, Eulophidae, Encyrtidae, Braconidae and Figitidae.

The differences showed in this research regard to distance gradients of the native riparian forest area in relation to rice crop highlight the importance of this refuge for parasitoids diversity, mainly in the conventional management area, where there is no levees vegetation. In the organic management, it influences is not seen, probably due to levees vegetation presence, that can provide refuge, shelter and ecological corridors for natural enemies. The chemical insecticides in rice crops can change parasitoids diversity through changes of selective inseticides to natural enemies (growth regulators) to non-selective (neurotoxic). The phenological stage of rice influences the parasitoids diversity on site and it must be related to different hosts, oftentimes phytophagous insects, in each crop development. Many studies show that the interaction plant-natural enemies is mediated by herbivore and oviposition-induced plant volatiles (HIPVs and OIPVs, respectively) in crop systems. The plants use them against herbivores, and it can vary according to the herbivore and phenology of the plant itself (Blassioli-Moraes et al., 2016).

\section{Acknowledgements}

The authors would like to thank COOPAN (Agricultural Production Cooperative Nova Santa Rita), Mr. Denis rice farmer and $\mathrm{CNPq}$ for financial support.

\section{References}

ACOSTA, L.G., JAHNKE, S.M., REDAELLI, L.R. and PIRES, P.R.S., 2017. Insect diversity in organic rice fields under two management systems of levees vegetation. Brazilian Journal of Biology $=$ Revista Brasileira de Biologia, vol. 77, no. 4, pp. 731-744. PMid:28355392.

ALTIERI, M.A., SILVA, E.N. and NICHOLLS, C.I. 2003. $O$ papel da biodiversidade no manejo de pragas. Ribeirão Preto: Holos. 223 p.

AYRES, M., AYRES, M.J., AYRES, D.L. and SANTOS, A.A.S. 2011. BioEstat 5.3: Aplicações Estatísticas nas Áreas das Ciências Biológicas e Médicas. 5. ed. Belém: Publicações Avulsas do Mamirauá, 361 p.

BAGGEN, L.R. and GURR, G.M., 1998. The Influence of Food on Copidosoma koehleri (Hymenoptera: Encyrtidae), and the Use of Flowering Plants as a Habitat Management Tool to Enhance Biological Control of Potato Moth, Phthorimaea operculella (Lepidoptera: Gelechiidae). Biological Control, vol. 11, no. 1, pp. 9-17. http://dx.doi.org/10.1006/bcon.1997.0566.

BASTOS, C.S., ALMEIDA, R.P. and SUINAGA, F., 2006. Selectivity of pesticides used on cotton (Gossypium hirsutum) to Trichogramma pretiosum reared on two laboratory-reared hosts.
Pest Management Science, vol. 62, no. 1, pp. 91-98. http://dx.doi. org/10.1002/ps.1140. PMid:16308868.

BAYEGAN, Z.A., HOSSEIN, H. and MOHAMMAD, R.Z., 2015. Occurrence of eulophid wasps (Hymenoptera: Chalcidoidea, Eulophidae) in rice fields of eastern Guilan, Iran. Journal Crop Protection, vol. 4, no. 2, pp. 199-205.

BLASSIOLI-MORAES, M.C., BORGES, M., MICHEREFF, M.F.F., MAGALHÃES, D.M. and LAUMANN, R.A., 2016. Semiochemicals from plants and insects on the foraging behavior of Platygastridae egg parasitoids. Pesquisa Agropecuária Brasileira, vol. 51, no. 5, pp. 454-464. http://dx.doi.org/10.1590/S0100204X2016000500005.

BRASIL. Ministério da Agricultura, Pecuária e Abastecimento. Coordenação Geral de Agrotóxicos e Afins. Sistema de Agrotóxicos Fitossanitários-AGROFIT, 2016 [viewed 7 August 2016]. Consulta Aberta [online]. Available from: http://agrofit.agricultura.gov.br/ agrofit_cons/principal_agrofit_cons

CASIDA, J.E. and DURKIN, K.A., 2013. Neuroactive insecticides: Targets, selectivity, resistance, and secondary effects. Annual Review of Entomology, vol. 58, no. 1, pp. 99-117. http://dx.doi. org/10.1146/annurev-ento-120811-153645. PMid:23317040.

CHAY-HERNANDEZ, D.A., DELFÍN-GONZÁLEZ, H. and PARRA-TABLA, V., 2006. Ichneumonoidea (Hymenoptera) community diversity in an agricultural environment in the State of Yucatan, Mexico. Environmental Entomology, College Park, vol. 35, no. 5, pp. 1286-1297. http://dx.doi.org/10.1603/0046225X(2006)35[1286:IHCDIA]2.0.CO;2.

CORBETT, A. and PLANT, R.E., 1993. Role of Movement in the Response of Natural Enemies to Agroecosystem Diversification: A Theoretical Evaluation. Environmental Entomology, vol. 22, no. 3, pp. 519-531. http://dx.doi.org/10.1093/ee/22.3.519.

COUNCE, P., KEISLING, T.C. and MITCHELL, A.J., 2000. A uniform, objective, and adaptative system for expressing rice development. Crop Science, vol. 40, no. 2, pp. 436-443. http:// dx.doi.org/10.2135/cropsci2000.402436x.

DALE, D. 1994. Insect pests of the rice plant - their biology and ecology. In: E.A. Heinrichs, ed. Biology and management of rice insects. New York: Wiley Eastern Ltda, pp. 363-485.

DIDONET, J., DIDONET, A.P.P., ERASMO, E.L. and SANTOS, G.R., 2001. Incidência e densidade populacional de pragas e inimigos naturais em arroz de terras altas, em Gurupi-TO. Bioscience Journal, vol. 17, pp. 67-76.

EMPRESA BRASILEIRA DE PESQUISA AGROPECUÁRIA - EMBRAPA, 2009 [viewed 1 September 2016]. Cultivo de arroz irrigado orgânico no Rio Grande do Sul [online]. Editores técnicos, Maria Laura Turino MATTOS, José Francisco da Silva MARTINS. Pelotas: Embrapa Clima Temperado, 161 p. Sistemas de Produção, no. 17 Available from: http://ainfo.cnptia.embrapa. br/digital/bitstream/item/46576/1/sistema-17.pdf

FERREIRA, M.L.G., JAHNKE, S.M., MORAIS, R.M. and DA SILVA, G.S., 2014. Diversidad de insectos depredadores en área orizícola orgánica y de conservación, en Viamão, RS. Brasil. Revista Colombiana de Entomologia, vol. 40, pp. 120-128.

FRITZ, L. L., HEINRICHS, E.A., MACHADO, V., ANDREIS, T.F., PANDOLFO, M., SALLES, S.M., OLIVEIRA, J.V. and FIUZA, L.M., 2011. Diversity and abundance of arthropods in subtropical rice growing areas in the Brazilian south. Biodiversity and Conservation, vol. 20, pp. 2211-2224. 
GANGURDE, S., 2007. Aboveground arthropod pest and predator diversity in irrigated rice (Oryza sativa L.) production systems of the Philippines. Journal of Tropical Agriculture, vol. 45 , no. $1-2$, pp. $1-8$.

GOULET, H. and HUBER, J.T., 1993. Hymenoptera of the World: an identification guide to families. Ottawa: Agriculture Canada Publication, $668 \mathrm{p}$.

GREENACRE, M. and HASTIE, T., 1987. The geometric interpretation of correspondence analysis. Journal of the American Statistical Association, vol. 82, no. 398, pp. 437-447. http://dx.doi. org/10.1080/01621459.1987.10478446.

GULLAN, P.J. and CRANSTON, P.S., 2008. Os Insetos: um resumo de entomologia. 3. ed. São Paulo: Roca Ltda, 440 p.

GUMOVSKY, A., POLASZEK, A., MURPHY, S.T., RABBI, M.F. and ZHU, C.D., 2006. Closterocerus oryzamyntor (Hymenoptera: Eulophidae: Entedoninae), a larval parasitoid of the rice hispa Dicladispa armigera in Bangladesh (Coleoptera: Chrysomelidae: Hispinae). Zootaxa, vol. 1241, pp. 51-59.

GURR, G.M., LIU, L., READ, D.M.Y., CATINDIG, J.L.A., CHENG, J.A., LAN, L.P. and HEONG, K.L., 2011. Parasitoids f Asian rice planthopper (Hemiptera: Delphacidae) pests and prospects for enhancing biological control by ecological engineering. Annals of Applied Biology, vol. 158, pp. 149-176. http://dx.doi. org/10.1111/j.1744-7348.2010.00455.X

HAMMER, O., HARPER, D.A.T. and RYAN, P.D., 2001. PAST: paleontological statistics software package for education and data analysis. Palaeontologia Electronica, vol. 4, no. 1, pp. 1-9.

HANSON, P.E. and GAULD, I.D., 2006. Hymenoptera de la región neotropical. Gainsville: The American Entomological Institute, vol. 77, 994 p.

INSTITUTO NACIONAL DE COLONIZAÇAÕ E REFORMA AGRÁRIA - INCRA, 2007. Relatório Ambiental do Projeto de Assentamento Capela. Porto Alegre: INCRA. 95 p.

KHAN, Z.R., BARRION, A.T., LITSINGER, J.A., CASTILLA, N.P. and JOSHI, R.C., 1988. Mini review: a bibliography of rice leaffolders (Lepidoptera: Pyralidae). Insect Science and its Applications, vol. 9, pp. 129-174.

KRAKER, J., VAN HUIS, A., HEONG, K.L., VAN LENTEREN, J.C. and RABBINGE, R., 1999. Population dynamics of rice leaffolders (Lepidoptera: Pyralidae) and their natural enemies in irrigated rice in the Philippines. Bulletin of Entomological Research, vol. 89, no. 05, pp. 411-421. http://dx.doi.org/10.1017/ S0007485399000541.

LANNER, A.J. 2011. A Cooperativa de produção agropecuária Nova Santa Rita Ltda (COOPAN) do Assentamento Capela, Nova Santa Rita (RS): questões da atividade suinícola. Porto Alegre: Faculdade de Ciências Econômicas da UFRGS, 104 p. Trabalho de Conclusão do Curso de Graduação Tecnológica em Planejamento e Gestão para o Desenvolvimento Rural - PLAGEDER.

LIERE, H., KIM, T.N., WERLING, B.P., MEEHAN, T.D., LANDIS, D.A. and GRATTON, C., 2015. Trophic cascades in agricultural landscapes: indirect effects of landscape composition on crop yield. Ecological Applications, vol. 25, no. 3, pp. 652-666. http://dx.doi.org/10.1890/14-0570.1. PMid:26214911.

MACIEL, A.A., LEMOS, R.N., SOUZA, J.R., COSTA, V.A., BARRIGOSSI, J.A. and CHAGAS, E.F., 2007. Parasitismo de Ovos de Tibraca limbativentris Stal (Hemiptera: Pentatomidae) na Cultura do Arroz no Maranhão. Neotropical Entomology, vol. 36, no. 4, pp. 616-618. http://dx.doi.org/10.1590/S1519566X2007000400023. PMid:17934631.
MAGURRAN, A.E., 2011. Medindo a diversidade biológica. Curitiba: Editora UFPR, $261 \mathrm{p}$.

MARCOS, T.F., FLOR, L.B., VELILLA, A.R., SCHOENLY, K.G., MANALO, J.O., OFILAS, O.M., TENG, P.S., ULEP, J.R., TINGUIL, M.B., ESTOY, A.B., COCSON, L.G. and OBIEN, S.R., 2001.Relationships between pests and natural enemies in rainfed rice and associated crop and wild habitats in Ilocos Norte, Philippines. In: T.W. Mew, E. Borromeo and B. Hardy, eds. Proceedings of the Impact Symposium on Exploiting Biodiversity for Sustainable Pest Management, 21-23 August 2000, Kunming China. The Philippines: International Rice Research Institute, pp. 23-24.

MINGOTI, S.A. 2005. Análise de dados através de métodos de estatística multivariada - uma abordagem aplicada. Belo Horizonte: Editora UFMG, 295 p.

MINISTÉRIO DO DESENVOLVIMENTO AGRÁRIO. INSTITUTO NACIONAL DE COLONIZAÇÃO E REFORMAAGRÁRIA INCRA. Superintendência Regional do Rio Grande do Sul 2010. PRA - Plano de recuperação do assentamento capela. Arambaré: COPTEC, $150 \mathrm{p}$

NACRO, S., DAKOUO, D. and HEINRICHS, E.A., 1997. Population dynamics, host plant damage and parasitism associated with the African rice gall midge in southern Burkina Faso. Insect Science and Its Application, vol. 16, pp. 251-257.

PALADINI, A., DOMAHOVSKI, A.C., KRINSKI, D. and FOERSTER, L.A., 2018. Reports of new wing color polymorphism and taxonomic information to cercopids (Auchenorrhyncha: Cercopidae) from upland rice crop, Pará State, Brazil. Brazilian Journal of Biology, vol. 78. no. 4. http://dx.doi.org/10.1590/15196984.175519.

PLEĆAŠ, M., GAGIĆ, V., JANKOVIĆ, M., PETROVIĆOBRADOVIĆ, O., KAVALLIERATOS, N.G., TOMANOVIĆ, Ž., THIES, C., TSCHARNTKE, T. and ĆETKOVIĆ, A. 2014. Landscape composition and configuration influence cereal aphid-parasitoid-hyperparasitoid interactions and biological control differentially across years. Agriculture, Ecosystems \& Environment, vol. 183, pp. 1-10. http://dx.doi.org/10.1016/j. agee.2013.10.016.

POWELL, W. 1986. Enhancing parasitoid activity in crops. In: J. Waage and D. Greathead, eds. Insect Parasitoids. London: Academic Press, pp. 319-340.

RIFFEL, C.T., PRANDO, H.F. and BOFF, M.I.C., 2010. Primeiro relato de ocorrência de Telenomus podisi (Ashmead) e Trissolcus urichi (Crawford) (Hymenoptera: Scelionidae) como parasitoides de ovos do Percevejo-do-Colmo-do-Arroz, Tibraca limbativentris (Stål) (Hemiptera: Pentatomidae), em Santa Catarina. Neotropical Entomology, vol. 39, no. 3, pp. 447-448. http://dx.doi.org/10.1590/ S1519-566X2010000300021. PMid:20676521.

ROMEIS, J., BABENDREIER, D., WACKERS, F.L. and SHANOWER, T.G., 2005. Habitat and plant specifity of Trichogramma egg parasitoids - underlying mechanisms and implications. Basic and Applied Ecology, vol. 6, no. 3, pp. 215236. http://dx.doi.org/10.1016/j.baae.2004.10.004.

SHARKEY, M.J., 2007. Phylogeny and classification of Hymenoptera. Zootaxa, vol. 1668, pp. 521-548.

SIMÕES-PIRES, P.R., JAHNKE, S.M. and REDAELLI, L.R., 2016. Influence of the vegetation management of the leeves in irrigated rice organic in diversity of Hymenoptera parasitoids. Brazilian Journal of Biology = Revista Brasileira de Biologia, , vol. 76, no. 3, pp. 774-781. http://dx.doi.org/10.1590/1519-6984.06215. 
SOCIEDADE SUL-BRASILEIRA DE ARROZ IRRIGADO - SOSBAI, 2012. Arroz irrigado: recomendações técnicas da pesquisa para o Sul do Brasil. In: Resumos da XXIX Reunião Técnica da Cultura do Arroz Irrigado, 01 a 03 de Agosto de 2012, Gravatal, SC. Itajaí: SOSBAI, 179 p.

SOCIEDADE SUL-BRASILEIRA DE ARROZ IRRIGADO - SOSBAI, 2014. Arroz irrigado: recomendações técnicas da pesquisa para o Sul do Brasil. In: Resumos da XXX Reunião Técnica da Cultura do Arroz Irrigado, 06 a 08 de agosto de 2014, Bento Goncalves, RS. Itajaí: SOSBAI, 192 p.

SOUZA DA SILVA, G., MUNDSTOCK JAHNKE, S. and GONZÁLEZ FERREIRA, M.L., 2016. Hymenoptera parasitoids in protected area of Atlantic Forest biomes and organic rice field: 2 compared assemblages. Revista Colombiana de Entomologia, vol. 42, no. 2, pp. 110-117. http://dx.doi.org/10.25100/socolen. v42i2.6680.

TANAKA, K., ENDO, S. and KAZANO, H., 2000. Toxicity of insecticides to predators of rice planthoppers: Spiders, the mirid bug and the dryinid wasp. Applied Entomology and Zoology, vol. 35, no. 1, pp. 177-187. http://dx.doi.org/10.1303/aez.2000.177.
TAXAPAD, 2012 [viewed 4 November 2015]. Catalogue of Life: 2012 Annual Checklist [online]. Available from: http://www. catalogueoflife.org/annual-checklist/2012/details/database/id/68

TOWNES, H., 1972. A light-weight Malaise trap. Entomological News, vol. 83, no. 9, pp. 239-247.

WILLIAMS, C.T., OKHIDIEVBIE, O., HARRIS, K.M. and UKWUNGWU, M.N., 1999. The host range, annual cycle and parasitoids of the African rice gall midage Orseoli oryzivora (Diptera: Cecidomyiidae) in central and southeast Nigeria. Bulletin of Entomological Research, vol. 89, no. 06, pp. 589-597. http:// dx.doi.org/10.1017/S0007485399000747.

ZHAO, Z.H., HUI, C., LI, Z.H. and LI, B.L., 2015. Habitat heterogeneity stabilizes the spatial and temporal interactions between cereal aphids and parasitic wasps. Basic and Applied Ecology, vol. 16, no. 6, pp. 510-518. http://dx.doi.org/10.1016/j. baae.2015.06.002.

ZHENG, X., YU, X., LU, Z., CHEN, J. and XU, H., 2003. Effects of different nutritional resources on the longevity and parasitic ability of egg parasitoid Anagrus nilaparvatae. Ying Yong Sheng Tai Xue Bao, vol. 14, no. 10, pp. 1751-1755. PMid:14986381. 